ATTHULAB:

Islamic Religion Teaching $\mathcal{E}$ Learning Journal

Volume 4 Nomor 2 Tahun 2019

http://journal.uinsgd.ac.id./index.php/atthulab/

\title{
الطلاب
}

\section{Tantangan pemahaman standar penilaian tenaga pendidik pada madrasah}

\author{
Ana Syifaunajah ${ }^{1}$ dan Fajar Meihadi2) \\ Madrasah Tsanawiyah As-Sa'adah Sumedang \\ Komplek MTs-MA As-Sa'adah Sukasari Kab. Sumedang Jawa Barat 45366 Indonesia \\ 1)Email: anasyifa16juni@gmail.com \\ 2)Email: fajarmeihadi1@gmail.com
}

\begin{abstract}
Achievement of National Standards Education for madrasas is one of the successes and quality of education. So this study aims to obtain a profile of understanding and achieving the National Education Standards in the school environment. The research method used is descriptive qualitative method using an instrument in the form of interview guidelines on national education standards data sources obtained from principals and 3 (three) PAI teachers. The results of the study indicate that there are variations in understanding of assessment standards. In addition, there is a different understanding of the standard of assessment between the principal and teacher. So that the results of this study have implications for the importance of socializing the standard components of evaluation to all educators in a school / madrasah.

Keywords:

assessment standards; national education standards
\end{abstract}

\begin{abstract}
Abstrak: Pencapaian Standar Nasional Pendidikan bagi madrasah merupakan salah satu keberhasilan dan mutu pendidikannya. Sehingga penelitian ini bertujuan untuk memperoleh profil pemahaman dan pencapaian Standar Nasional Pendidikan di lingkungan sekolah. Metode penelitian yang digunakan ialah metode deskriptif kualitatif dengan menggunakan instrument berupa pedoman wawancara tentang standar nasional pendidikan sumber data diperoleh dari kepala sekolah dan 3 (tiga) orang guru PAI. Hasil penelitian menunjukkan bahwa adanya variasi pemahaman tentang standar penilaian. Selain itu, terdapat pemahaman yang berbeda tentang standar penilaian antara kepala sekolah dan guru. Sehingga hasil penelitian ini berimplikasi terhadap pentingnya sosialisasi komponen-komponen standar evaluasi kepada seluruh pendidik di suatu sekolah/madrasah.
\end{abstract}

\author{
Kata kunci: \\ standar penilaian; standar nasional pendidikan \\ DOI: http:/ /dx.doi.org/10.15575/ath.v4i2.4448 \\ Received: 05, 2019. Accepted: 10, 2019. Published: 11, 2019
}

\section{PENDAHULUAN}

Mutu pendidikan di semua jenjang dan jenis pendidikan sangat tergantung kepada kualitas layanan sarana dasar baik yang menyangkut fisik maupun non fisik. Di Indonesia, suatu lembaga pendidikan dikatakan layak jika telah memenuhi standar minimal layanannya. Pemenuhan layanan ini secara nasional ditetapkan Pemerintah melalui Peraturan Pemerintah No. 19 Tahun 2005 tentang Standar Nasional Pendidikan. Strategi layanan tersebut terdiri dari delapan standar, yaitu standar isi; lulusan; proses; sarana dan prasarana; pengelolaan; pendidik dan tenaga kependidikan; pembiayaan; dan penilaian. Salah satu standar untuk memastikan kualitas penilaian keberhasilan pendidikan ditentukan oleh standar penilaian. Pencapaian Standar Nasional Pendidikan bagi madrasah merupakan salah satu keberhasilan dalam meningkatkan mutu pendidikan. Sehingga penelitian ini bertujuan untuk memperoleh profil 
pemahaman dan pencapain Standar Nasional Pendidikan di lingkungan sekolah. Standar Nasional Pendidikan dibuat sebagai acuan dan pedoman dalam melaksanakan pendidikan di Indonesia, yang merupakan kebijakan pemerintah dalam meningkatkan kualitas pendidikan. Kebijakan yang dapat digunakan sebagai acuan dalam mengelola pendidikan adalah Peraturan Pemerintah Republik Indonesia Nomor 19 Tahun 2005 tentang Standar Nasional Pendidikan (Departemen Pendidikan Nasional. 2003). Artinya, bahwa adanya Standar Nasional Pendidikan dibuat sebagai pedoman bagi seluruh institusi atau lemabaga pendidikan di Indonesia.

Dalam jurnalnya (Sabar Budi Raharjo 2014) mengenai kontribusi delapan standar pendidikan, Sudrajat (2010) mengatakan bahwa Standar Nasional Pendidikan memiliki fungsi sebagai dasar dalam perencanaan, pelaksanaan, dan pengawasan pendidikan dalam rangka mewujudkan pendidikan nasional yang bermutu, dan bertujuan untuk menjamin mutu pendidikan nasional dalam rangka mencerdaskan kehidupan bangsa dan membentuk watak serta peradaban bangsa yang bermartabat. Dengan demikian, dikatakan bahwa pendidikan yang ada di Indonesia harus mengacu kepada pemerintah yang telah tercantum di dalam Standar Nasional Pendidikan yang menjadi dasar utama pendidikan yang harus dilaksanakan oleh setiap lembaga pendidikan, yang bertujuan untuk meningkatkan taraf pendidikan ke arah yang lebih baik dan lebih berkualitas. Penilaian atau asesmen adalah istilah umum yang mencakup semua metode yang biasa digunakan untuk menilai kemampuan individu peserta didik atau kelompok (Mustikawan 2013). Artinya, penilaian tersebut mencakup semua aspek yang terdapat dalam diri peserta didik. Selain itu, penilaian juga dilakukan dengan berbagai metode atau pendekatan peserta didik dengan menggunakan lembar penilaian, observasi, penelitian sesuai dengan kurikulum yang berlaku.

Pemenuhan standar penilaian pada suatu lembaga pendidikan menjadi sangat penting. Semua kegiatan perencanaan, proses pendidikan dan pengembangan didasari pada proses penilaian. Penilaian terhadap proses dan hasil pembelajaran berkontribusi terhadap keberhasilan mengajar. Selain itu, sasaran yang paling utama dari proses penilaian adalah dapat diketahuinya tingkat pencapaian kompetensi peserta didik. Karena capaian kompetensi peserta didik menyangkut aspek kognitif, keterampilan, dan aspek sikap. Namun saat ini, banyak lembaga pendidikan yang belum memenuh standar nasional pendidikan. Seperti beberapa penelitian menyimpulkan bahwa kontribusi delapan standar masih relatif kecil dan perlu memperhatikan faktor lain di luar standar dalam perbaikan mutu prestasi belajar (Raharjo, 2014). Demikian pula Miarso (2008) menyebutkan bahwa pemenuhan standar nasional pendidikan termasuk kualitas guru dapat menentukan kualitas pendidikan secara keseluruhan. Sedangkan Baharun (2016) meyakini bahwa evaluasi merupakan komponen penting yang harus diambil oleh guru untuk mengetahui efektifias pembelajaran yang telah dilakukan. Selain itu, hasil yang diperoleh dari evaluasi dapat digunakan sebagai umpan balik bagi pendidik dalam meningkatkan kegiatan pembelajaran. Sejalan dengan itu, bahwa pencapaian standar penilaian pendidikan dapat memprediksi keberhasilan akreditasi sekolah (Rembang dkk, 2017). Beberapa penelitian di atas menunjukkan bahwa pencapaian standar penilaian berkontribusi terhadap kualitas pendidikan. Namun ada beberapa aspek yang belum terungkap, diantaranya apakah pencapaian standar nasional pendidikan khususnya standar penilaian ditentukan pula oleh pemahaman pendidik dan tenaga kependidikan di suatu sekolah/madrasah.

Pelaksanaan pendidikan, dan tindak lanjut menyangkut merupakan salah satu standar nasional pendidikan yang harus diterapkan dalam proses belajar mengajar, karena penilaian merupakan standar yang amat penting dilakukan oleh pendidik untuk 
mengetahui sejauh mana kemampuan peserta didik, serta untuk mengevaluasi setiap proses pembelajaran. Penilaian tersebut, bukan hanya sekedar penilaian kognitif, akan tetapi afektif dan psikomotor juga termasuk tanggung jawab dan kewajiban peserta didik dalam memberikan penilaian. Menurut Amrullah fungsi dari penilaian pendidik terhadap peserta didik ialah untuk mengetahui seberapa banyak indikator kompetensi dasar suatu mata pelajaran tercapai, menilai kebutuhan individual, dan lain sebagainya (Amrullah 2017).

Seperti diyakini bahwa penilaian yang dilakukan oleh pendidik kepada peserta didik memiliki tujuan dan manfaat yang sangat penting. Bahkan proses penilaian yang tepat dapat menentukan capaian dan luar biasa bagi kemajuan pendidik dan ataupun bagi peserta didik dalam proses pembelajarannya. Akan tetapi, realitas yang ada mengenai konsep dan aplikasinya tidak begitu mulus sebagian pendidik pada realitanya masih kurang menguasai proses mengindahkan konsep penilaian sesuai dengan rambu-rambu dalam standar nasional pendidikan. yang diberikan oleh pemerintah, sehingga akibatnya penilaian proses dan hasil pembelajaran dari pendidik kepada peserta didik pun tidak maksimal. Terdapat beberapa kendala yang dihadapi dan terjadi di sekolah dan madrasah, antara lain belum meratanya pemahaman pendidik dan tenaga kependidikan dalam merencanakan, melaksanakan dan mengevalasi system penilaian pembelajarannya. Seperti disimpulkan oleh Susila (2012) bahwa sumber kenadala yang dihadapi oleh pendidik mengalami kesulitan dalam menilai unjuk kerja peserta didik. Kesulitannya antara lain dalam diantaranya, pedoman penyekoran dalam instrument tidak jelas sehingga sukar digunakan, komponen-komponen yang dinilai sulit untuk diamati, sehingga cenderung diabaikan (Susila 2012). Keadaan tersebut tersebut merupakan salah satu kendala dalam penilaian yang dilakukan oleh pendidik.

Oleh sebab itu, tulisan ini bertujuan untuk menganalisis pemahaman guru, pendidik khususnya guru endidikan Agama Islam (PAI) terhadap standar penilaian yang didasarkan berlandaskan kepada indikaor-indikator yang terdapat pada kebijakan pemerintah dalam Standar Nasional Pendidikan. Pemahaman standar penilaian pendidik tersebut bertujuan untuk mengungkap mengetahui sejauh mana guru memahmi konsep penilaian. Konsep penilaian yang dilakukan oleh pendidik terhadap kepada peserta didik menyangkut baik itu penilaian dalam ranah kognitif, afektif apektif maupun dan psikomotor. Hasil analisis, kesimpulan dan rekomendasi yang disusun berdasarkan penelitian ini dapat digunakan untuk mengambil kebijakan. Kebijakan yang dapat dilakukan untuk madrasah umumnya dan untuk memperbaiki mekanisme evaluasi pada Madrasah Tsanawiyah As-Sa'adah yang bertujuan untuk meningkatkan mutu pendidikan di Indonesia ke taraf yang lebih baik.

\section{METODE PENELITIAN}

Metode yang digunakan dalam penelitian pembahasan artikel ini ialah deskriptif partisipatoris pendekatan kuanlitatif dan metode yang digunakan dalam penelitian ini deskriptif analisis. Metode ini yang digunakan untuk memecahkan permasalahan dengan cara menjawab, memaparkan atau menggambarkan pemahaman hasil dari partisipan tenaga pendidik terhadap indicator-indikator standar penilaian. suatu penelitian. Adapun ruang lingkup indicator standar penilaian yang digunakan dalam penelitian ini berjumlah 16 indikator. Keenambelas indicator tersebut adalah: (1) penyusunan RPP berdasarkan silabus, (2) melaksanakan proses pembelajaran, (3) menyusun kisi-kisi penilaian, (4) membuat instrumen penilaian dan pedoman penilaian, (5) mengamati perilaku peserta didik, (6) mencatat perilaku peserta didik, (7) 
tindaklanjut hasil pengamatan, (8) mendeskripsikan perilaku peserta, (9) menyusun perencanaan penilaian, (10) melaksanakan evaluasi pembelajaran, (11)melaksankan penilaian hasil belajar, (12) melaporkan hasil penilaian, (13) mengembangkan instrumen penilaian, (14) melaksanakan penilaian sesuai dengan rencana, (15) melakukan remedial, dan (16) melaporkan hasil penilaian. Keenam belas indicator ini menjadi parameter kondisi mutu lembaga dalam merencanakan, melaksanakan dan mengevaluasi system penilaian yang digunakan oleh lembaga maupun kemampuan tenaga pendidik sebagai sumber data. Sumber-sumber diperoleh dari observasi. Pengumpulan data dilakukan dengan mengamati dan mencatat jawaban mengenai pemahaman penilaian yang diselidiki dengan menggunakan pedoman wawancara. dan angket tentang standar penilaian pendidikan, kemudian menga mbil kesimpulan secara reduktif melalui analisis. Angket yang digunakan dalam penelitian ini ialah angket terbuka dan tertutup. dengan menggunakan skala Likert dari angka $0-5$. , yang memiliki tujuan untuk memperoleh jawaban dari kepala sekolah dan guru PAI.

Sumber data dalam penelitian ini diperoleh dari guru dan kepala madrasah sebagai sumber data primer. Sumber data ini digunakan karena mereka merupakan pelaksana langsung dan merupakan pembina akademik di madrasah. Sehingga data yang diperoleh akan valid dan obyektif. Partisipan terdiri dari seorang kepala madrasah dan 3 orang guru PAI yang dipilih secara purposive. Adapun lokasi penelitian dilakukan di Madrasah Tsanawiyah As-Sa'adah Jatinangor Kabupaten Sumedang. Sumber data lain yang digunakan adalah dokumentasi seperti profil madrasah dan berkas hasil akreditasi madrasah periode terakhir.

Instrumen penelitian yang digunakan berupa pedoman wawancara yang merujuk kepada 16 indikator standar evaluasi. Validitas intrumen dilakukan secara konstruk oleh beberapa orang Dosen dan Tenaga Pendidik senior dari kalangan madrasah. Berdasarkan instrument tersebut akan diperoleh data jumlah indicator yang dipahami oleh Kepala Madrasah maupun Guru. Data kuantitatif akan diperoleh berdasarkan jumlah indicator yang dianggap telah dipahami oleh para partisipan. Berdasarkan jumlah indicator tersebut maka dapat diperoleh prosentase keterpahaman partisipan terhadap standar evaluasi. Setelah diperoleh data prosentase, maka dilakukan triangulasi terhadap jawaban-jawaban partisipan. Triangulasi ini dilakukan untuk mendapatkan data tambahan yang lebih mendalam dari pemahaman mereka terhadap indicator-indikator standar evaluasi yang belum optimal.

Pada bagian akhir penelitian ini akan dilakukan analisis kuantitatif sederhana. Yaitu mendeskripsikan jumlah indicator standar evaluasi yang dipahami. Selanjutnya dilakukan analisis kualitatif yaitu dengan menginterpretasikan keseluruhan hasil analisis data. Hasil analisis ini akan digunakan untuk menyusun kesimpulan. Pada akhirnya, berdasarkan kelemahan dan kekurangan proses dan hasil penelirian ini akan dirumuskan beberapa rekomendasi yang relevan.. sumber data primer dan sumber data sekunder. Sumber data primer yaitu sumber data yang pokok diperoleh dalam bentuk verbal atau ucapan lisan dan perilaku dari subjek (informan) berkaitan dengan permasalahan penelitian. Dalam penelitian ini, sumber data pokok diperoleh dari kepala sekolah MTs As-sa'adah dan 3 (tiga) orang guru PAI. Sedangkan sumber data sekunder adalah sumber data penunjang berasal dari dokumen, prosedur madrasah, profil madrasah, dan benda yang erat hubungannya dengan fokus penelitian. Tujuan dari penelitian ini adalah untuk mengungkap pemahaman kepala sekolah dengan pendidik mengenai standar penilaian.

Setelah peneliti mendapatkan data kemudian diolah dengan menggunakan metode dekriptif analisis yaitu menganalisis data yang dikumpulkan berupa kata-kata, 
dan bukan angka. Data yang diperoleh dari wawancara, penyebaran angket serta observasi dianalisis sehingga dapat memberikan kejelasan terhadap kenyataan atau realitas menyeluruh mengenai pemahaman penilaian. Kegiatan analisis data dilakukan dengan pendekatan logika untuk data kualitatif dan pendekatan statistika untuk data kuantitatif dengan menggunakan analisis parsial.

\section{HASIL PENELITIAN DAN PEMBAHASAN}

Berdasarkan Hasil Analisis data penelitian akan menyajikan dua profil dan sebuah rumusan masalah dan alternative pemecahan masalah tentang pencapaian pemahaman standar penilaian. Kedua profil tersebut adalah distribusi partisipan berdasarkan indicator standar penilaian dan prosentase capaian masing-masing partisipan. Adapun profil distribusi partisipan berdasarkan indiaktor standar penilaian adalah sebagai berikut. pemahaman dan kemampuan tenaga pendidik terhadap standar penilaian, diperoleh profil pemahaman tenaga pendidik dan profil analisis komponen-komponen standar penilaian di MTs As-sa'adah. Untuk mengetahui pemahaman pendidik terhadap standar penilaian, maka peneliti mewawancarai kepada 3 (tiga) orang pendidik, dan 1 (satu) orang kepala sekolah di MTs As-sa'adah dengan mengajukan 16 pertanyaan berdasarkan indikator standar penilaian.

Untuk mengetahui nilai rata-rata seluruh pertanyaan, akan ditetapkan dengan menggunakan rumus $\mathrm{M}=(\mathrm{Fx}: \mathrm{n}) \mathrm{100}$. Adapun limit interval yang dimaksud adalah mengacu kepada pendapat (Syah, 2011:151), terdapat pada tabel 1. berikut:

Tabel 1. limit interval Pemahaman

\begin{tabular}{lcc}
\hline $80-100=$ sangat baik & $60-69=$ cukup & $0-49=$ gagal \\
$70-79=$ baik & $50-59=$ kurang & \\
\hline
\end{tabular}

\section{Ditribusi Pemahaman Partisipan berdasarkan indikator}

Distribusi partisipan tenaga pendidik berdasarkan indikator standar penilaian dapat dilihat pada tabel 2. berikut:

Tabel 2. Distribusi Pemahaman Partisipan berdasarkan Indikator Standar Penilaian

\begin{tabular}{llcccc}
\hline No & \multicolumn{1}{c}{ Indikator Standar Penilaian } & KS & GA & G1 & G2 \\
\hline 1 & Membuat RPP berdasarkan silabus & $\mathrm{V}$ & $\mathrm{V}$ & $\mathrm{V}$ & $\mathrm{V}$ \\
2 & Melaksanakan proses pembelajaran & $\mathrm{V}$ & $\mathrm{V}$ & $\mathrm{V}$ & $\mathrm{V}$ \\
3 & Menyusun kisi-kisi penilaian & $\mathrm{V}$ & $\mathrm{V}$ & $\mathrm{V}$ & $\mathrm{V}$ \\
4 & Membuat instrumen penilaian dan pedomannya & $\mathrm{V}$ & $\mathrm{V}$ & $\mathrm{V}$ & $\mathrm{V}$ \\
5 & Mengamati perilaku peserta didik & $\mathrm{V}$ & $\mathrm{V}$ & $\mathrm{V}$ & $\mathrm{V}$ \\
6 & Mencatat perilaku peserta didik dengan lembar & $\mathrm{V}$ & $\mathrm{V}$ & $\mathrm{V}$ & $\mathrm{V}$ \\
& observasi & & & & \\
7 & Menindaklanjuti hasil sikap peserta didik & $\mathrm{V}$ & - & - & $\mathrm{V}$ \\
8 & Mendeskripsikan perilaku peserta & $\mathrm{V}$ & $\mathrm{V}$ & $\mathrm{V}$ & $\mathrm{V}$ \\
9 & Menyusun perencanaan penilaian & $\mathrm{V}$ & $\mathrm{V}$ & $\mathrm{V}$ & $\mathrm{V}$ \\
10 & Melaksanakan evaluasi pembelajaran & $\mathrm{V}$ & $\mathrm{V}$ & $\mathrm{V}$ & $\mathrm{V}$ \\
11 & Melaksankan penilaian hasil belajar & $\mathrm{V}$ & $\mathrm{V}$ & $\mathrm{V}$ & $\mathrm{V}$ \\
12 & Melaporkan hasil penilaian & $\mathrm{V}$ & $\mathrm{V}$ & $\mathrm{V}$ & $\mathrm{V}$ \\
13 & Mengembangkan instrumen penilaian & $\mathrm{V}$ & $\mathrm{V}$ & $\mathrm{V}$ & $\mathrm{V}$ \\
14 & Melaksanakan penilaian sesuai dengan rencana & $\mathrm{V}$ & $\mathrm{V}$ & $\mathrm{V}$ & $\mathrm{V}$ \\
15 & Melakukan remedial & $\mathrm{V}$ & $\mathrm{V}$ & $\mathrm{V}$ & $\mathrm{V}$ \\
16 & Melaporkan hasil penilaian & $\mathrm{V}$ & $\mathrm{V}$ & $\mathrm{V}$ & $\mathrm{V}$ \\
& & 16 & 15 & 15 & 16 \\
& & 100 & 93,8 & 93,8 & 100 \\
\hline
\end{tabular}


Tabel 2 menunjukkan profil pemahaman seorang Kepala Madrasah dan 3 orang guru terhadap Standar Penilaian. Dari keenambelas indicator standar penilaian hanya ada satu indicator yang dikatakan belum paham oleh 2 (dua) orang guru. Indikator tersebut adalah cara menindaklanjuti hasil penilaian sikap peserta didik. Kedua orang guru tersebut adalah seorang guru Pendidikan Agama Islam dan 1 (satu) orang guru lainnya. Jumlah indicator standar penilaian yang dipahami oleh kedua guru tersebut adalah 15 buah indicator atau sebesar $93,8 \%$.

(paragraf kedua berisi hasil penelitian tentang standar penilaian dari minimal 3 jurnal internasional dan atau 5 jurnal nasional)

(paragraf ketiga berisi elaborasi dari hasil analisis paragraph 1 dan rangkuman hasil penelitian pada paragraf 2)

Grafik 1 menunjukkan adanya perbedaan pemahaman antara pendidik dengan kepala sekolah mengenai standar penilaian. Perbedaan pemahaman tersebut dilihat dari jumlah total semua pertanyaan yang diajukan kepada kepala sekolah yang mendapat jawaban "YA" sebanyak 16 pertanyaan

\section{Profil Pemahaman tenaga Pendidik}

Profil pemahaman tenaga pendidik dapat ditunjukkan dengan grafik berikut:

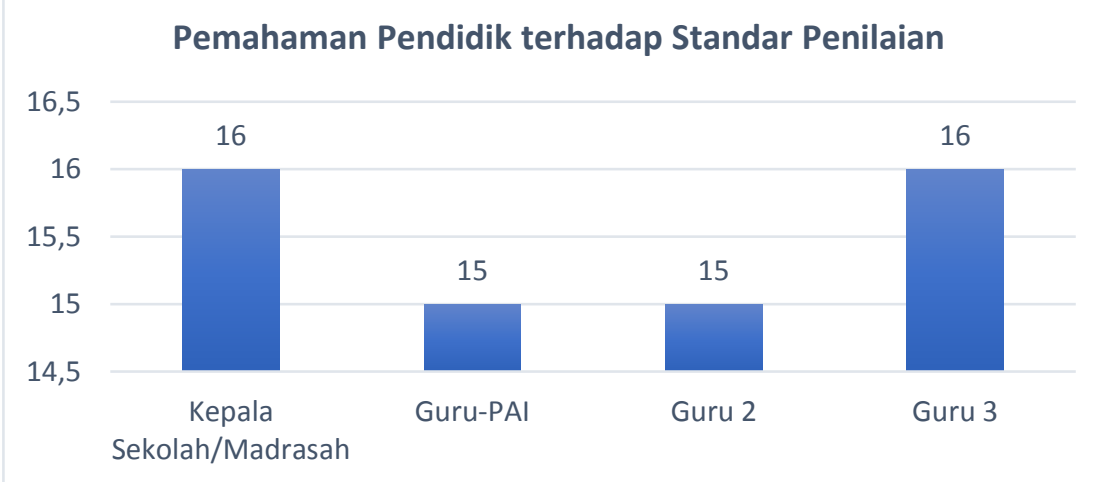

Grafik 1: Profil Pemahaman Tenaga Pendidik terhadap Standar Penilaian

Grafik 1 menunjukkan adanya perbedaan pemahaman antara pendidik dengan kepala sekolah mengenai standar penilaian. Perbedaan pemahaman tersebut dilihat dari jumlah total semua pertanyaan yang diajukan kepada kepala sekolah yang mendapat jawaban "YA" sebanyak 16 pertanyaan. Berbeda halnya dengan pendidik 1 (satu) dan 2 (dua) yang menjawab pertanyaan dengan jawaban "YA" sebanyak 15 pertanyaan. Perbedaan pemahaman tersebut terdapat pada item pertanyaan no. 8 dengan indikator pendeskripsian nilai afektif kedalam bentuk angka. Pendidik 1 (satu) dan 2 (dua) memiliki pemahaman bahwa pada kebijakan pemerintah sekarang di kurikulum 2013 ataupun kurikulum nasional, nilai afektif peserta didik itu tidak di deskripsikan dengan angka, akan tetapi menggunakan predikat yang tidak memiliki kriteria. Hal yang demikian, berbeda dengan pemahamannya kepala sekolah, bahwa beliau mengatakan, dalam kebijakan penilaian yang berlaku, afektif itu di deskripsikan ke dalam bentuk angka dan masuk kedalam aspek penilaian hasil belajar yang berada di bagian spiritual. Dengan demikian, berdasarkan penelitian dan analisis penulis, bahwa di MTs Assa'adah terdapat perbedaan pemahaman antara kepala madrasah dengan pendidik yang lainnya mengenai indikator penilaian sikap afektif. 


\section{Analisis Komponen Standar Penilaian}

Berdasarkan hasil analisis komponen strandar penilaian, dapat diperoleh dengan hasil yang tercantum pada Tabel 3. sebagai berikut:

Tabel 3 Distribusi Hasil Instrumen Standar Penilaian

\begin{tabular}{|c|c|c|c|c|c|c|}
\hline \multirow[t]{2}{*}{ No } & \multirow[t]{2}{*}{ Responden } & \multicolumn{4}{|c|}{ Jawaban } & \multirow[t]{2}{*}{ Keterangan } \\
\hline & & Ya & Prosentase & Tidak & Prosentase & \\
\hline 1. & $\begin{array}{l}\text { Kepala } \\
\text { Madrasah }\end{array}$ & 16 & $100 \%$ & - & - & \multirow{5}{*}{$\begin{array}{c}\text { Perbedaan terletak pada item } \\
\text { pertanyaan no. } 8 \\
\text { (pendeskripsian nilai } \\
\text { peserta didik) }\end{array}$} \\
\hline 2. & Guru 1 & 15 & $93,75 \%$ & 1 & $6,25 \%$ & \\
\hline 3. & Guru 2 & 15 & $93,75 \%$ & 1 & $6,25 \%$ & \\
\hline 4. & Guru 3 & 16 & $100 \%$ & - & - & \\
\hline & Rata-rata & 15,5 & $97 \%$ & 1 & $6,25 \%$ & \\
\hline
\end{tabular}

Rata-rata
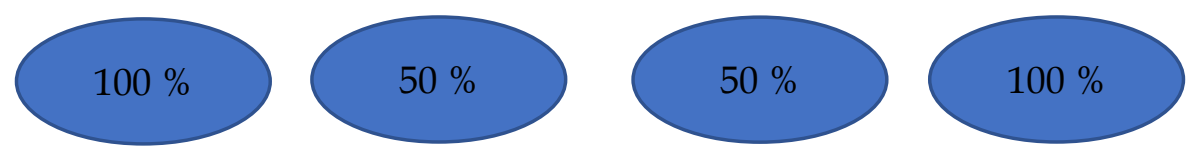

Dari tabel 2 mengenai distribusi hasil instrument standar penilaian bahwa kepala sekolah dan guru ke-3 (tiga) lah yang memiliki pemahaman yang sama dengan berdasarkan rumus $\mathrm{P}=\mathrm{f} / \mathrm{n} \times 100.16 / 16 \times 100=100 \%$. Artinya, antara kepala sekolah dan guru tidak terjadi perbedaan pemahaman mengenai standar penilaian. Akan tetapi, berbeda halnya dengan pemahaman guru 1 (satu) dan guru (2) yang memiliki pemahaman yang berbeda. Berdarakan rumus $15 / 16 \times 100=93,75 \%$ yang menjawab "YA". Dan yang menjawab "TIDAK" $1 / 16 \times 100=6,25 \%$. Artinya terdapat perbedaan pemahaman antara kepala sekolah dengan guru mengenai pendeskripsian afektif ke dalam bentuk angka. Apabila kita melihat rata-rata persentase yang berada di tabel 2, bahwa persentase ke 4 (empat) responden ialah $97 \%$ yang menjawab "YA", sedangkan persentase yang menjawab "TIDAK" sebanyak 6,25\% mengenai perbedaan pemahaman guru 1 (satu) dan guru 2 (dua). Pemaparan lebih rincinya akan dijelaskan pada paragraph selanjutnya.

Perbedaan antara pemahaman kepala sekolah dan guru-guru terhadap komponen standar penilaian, pertanyaan nomor 1, 2, 3, 4, 5, 6, 7, 9, 10, 11, 12, 14, 15 dan 16 yang berkaitan dengan standar penilaian, dengan indikator perntanyaan "pembuatan RPP, proses pembelajaran berdasarkan RPP, kisi-kisi penilaian, instrument dan pedoman penilaian, pengamatan perilaku peserta didik, pencatatan sikap peserta didik, penindaklanjutan hasil pengamatan, penyususnan rencana penilaian, pengadaan ulangan harian, penilaian UTS, UAS dan UKK, pelaporan hasil penilaian, penilaian sesuai rencana, remedial serta pelaporan hasil penilaian kepada kepala sekolah " pendidik dan kepala sekolah yang menjawab "YA" sebanyak 4 orang, dengan keterangan bahwa pembuatan RPP dibuat dan disusun oleh pendidik berdasarkan silabus dengan lengkap yang berisi seluruh komponen-komponen RPP seperti membuat kalender akademis, membuat program semesteran, program tahunan, instrument penilaian dan yang lain sebagainya yang dibuat setiap semester sebagai salah satu kewajiban yang harus oleh pendidik sebelum melaksanakan proses pembelajaran, serta sebagai acuan pendidik dalam proses pembelajaran.

Berdasarkan nilai yang diperoleh dari pertanyaan-pertanyaan tersebut, bahwa rata-rata yang diperoleh adalah $4: 4=1 \times 100=100$. Dengan berpedoman pada skala 
penilaian yang telah ditetapkan, nilai rata-rata tersebut, berada pada interval $80-100=$ sangat baik. Dengan demikian, pemahaman pendidik dan kepala sekolah mengenai standar penilaian berada pada interval yang sangat baik.

Adapun perbedaan pemahaman antara pendidik dan kepala sekolah, terdapat pada item no.8. Dengan pertanyaan item no. 8 mengenai indikator pendeskripsian afektif peserta didik, sebanyak 2 orang menjawab "YA" dan 2 orang yang menjawab "TIDAK". Hal yang demikian terjadi karena perbedaan pemahaman pendidik dengan kepala sekolah mengenai pendeskripsian nilai afektif peserta didik dalam bentuk angka. Karena, menurut pendidik, pada kebijakan pemerintah sekarang, afektif peserta didik itu tidak di deskripsikan dengan nilai, akan tetapi menggunakan predikat yang tidak memiliki kriteria. Hal yang demikian, berbeda dengan pemahamannya kepala sekolah, bahwa beliau mengatakan, dalam kebijakan penilaian sekarang, afektif itu di deskripsikan dengan angka dan masuk kedalam aspek penilaian hasil belajar yang berada di bagian spiritual.

Berdasarkan nilai yang diperoleh dari pertanyaan tersebut rata-rata yang diperoleh adalah 2:4 $=0,5 \times 100=50$. Dengan berpedoman pada skala penilaian yang telah ditetapkan, nilai rata-rata tersebut, berada pada interval $50-59=$ kurang. Dengan demikian, pemahaman pendidik mengenai standar penilaian berada pada interval yang kurang.

Perbedaan pemahaman tenaga pendidik terhadap standar penilaian diduga ditentukan oleh kurangnya sosialisasi yang dilakukan oleh MTs As-sa'adah terhadap pendidik. Sosialisasi sendiri memiliki arti proses belajar seorang anggota masyarakat untuk mengenal dan menghayati kebudayaan masyarakat di lingkungannya (Anjelica, Sharon, 2017). Sosialisasi juga diartikan sebagai usaha untuk mengembangkan profesionalisme pendidik secara berkelanjutan untuk menghasilkan pendidik yang profesional (Mei Chuo, 2011). Artinya, sosialisasi merupakan sebuah proses untuk menyampaikan informasi atau berita agar masyarakat umum mengetahuinya. Hal yang demikian sejalan dengan pendapatnya (Excerpt \& Entry, 2006) bahwa sosialisasi merupakan proses seorang individu memperoleh sikap, perilaku dan pengetahuan. Sosialisasi tidak akan terjadi apabila tidak adanya interaksi sosial antara pendidik dengan kepala sekolah. Menurut Soekarno interaksi sosial menjadi syarat utama terjadinya aktivitas-aktivitas sosial karena adanya kontak dan komunikasi dengan orang lain. Artinya, interaksi sosial tidak akan terjadi apabila tidak ada komunikasi, karena komunikasi sangat dibutuhkan dalam aspek manapun, proses komunikasi tersebut bertujuan agar terciptanya sumber daya manusia yang kooperatif dan mampu bersaing di dunia globalisasi (Soekanto, 2009:58).

Komunikasi sangat dibutuhkan untuk mendapatkan informasi (Wursanto, 2003:31). Dalam hal ini, komunikasi yang sangat dibutuhkan ialah komunikasi pendidik dengan pendidik, maupun komunikasi pendidik dengan kepala sekolah agar tidak terjadi perbedaan pemahaman mengenai standar penilaian. Selain itu, perbedaan pemahaman juga bisa terjadi karena kurangnya pertukaran informasi antara pendidik dengan pendidik, maupun pendidik dengan kepala sekolah, karena pada hakikatnya pertukaran informasi ini sangatlah diperlukan. Pertukaran pengetahuan (knowledge sharing) adalah aktivitas dimana pengetahuan (informasi, keterampilan dan keahlian) dipertukarkan antara orang-orang, kolega, komunitas dan organisasi. Rahman menyatakan bahwa pertukaran pengetahuan tersebut akan meningkatkan kapasitas individu guru sekaligus membentuk intelegensi kolektif sekolah (Rahman, 2016). Termasuk dalam hal ini, ialah pertukaran pengetahuan tentang pemahaman pendidik mengenai penilaian afektif yang di deskripsikan kedalam bentuk angka. 
Selain itu juga diperlukan pelatihan bagi para pendidik. MTs As-sa'adah juga perlu mengadakan pelatihan kepada para pendidik mengenai standar penilaian. Yang dimaksud dengan pelatihan itu sendiri yaitu "Training is the act of increasing the knowledge and skill of an employee for doing a particular job". (pelatihan adalah tindakan meningkatkan pengetahuan dan keterampilan seorang pegawai untuk melaksanakan pekerjaan tertentu"(Kamil, 2010:3). Pelatihan tersebut bertujuan agar semua tenaga pengajar dalam hal ini guru harus mampu menguasai metode-metode pembelajaran yang mutakhir (Hamsinah, 2016). Pelatihan tersebut apabila dikaitkan dengan standar penilaian, berarti pendidik harus menguasai metode-metode atau teknis yang harus digunakan dalam melakukan penilaian kepada pendidik agar tidak terjadi diskomunikasi antara pendidik dengan pendidik yang lainnya mengenai pemahaman standar penilaian.

Pendidikan dan pelatihan merupakan proses sistematis untuk meningkatkan, mengembangkan, dan membentuk pegawai dimana pegawai mempelajari pengetahuan (knowledge), keterampilan (skill), kemampuan (ability) atau perilaku terhadap tujuan pribadi dan organisasi sehingga terciptanya sumber daya manusia yang berkualitas (Rusdin, 2017). Artinya, pelatihan memiliki tujuan untuk memperbaiki dan mengembangkan pengetahuan, keterampilan pendidik. Dengan demikian, apabila sudah diadakan pelatihan, kemungkinan besar pemahaman pendidik dengan kepala sekolah tidak akan terjadi perbedaan pemahaman lagi, karena tujuan dari pelatihan itu ialah untuk memperbaiki dan mengembangkan sikap dan pengetahuan dalam suatu lembaga. Sedangkan manfaat pelatihan bagi guru diantaranya: (1) membantu para guru membuat keputusan dengan lebih baik; (2) meningkatkan kemampuan para guru menyelesaikan berbagai masalah yang dihadapinya; (3) terjadinya internalisasi dan operasionalisasi faktor-faktor motivasional;(Amaroh, n.d.). pelatihan disini bertujuan untuk menciptakan pendidik yang memiliki profesionalitas. Salah satu dari bagian pelatihan ialah diklat, tujuan umum diklat PTK PNF adalah untuk menghasilkan tenaga-tenaga yang terampil yang mampu menjadi tenaga pendidik yang menguasai konsep dan teori. Supriyono di dalam standar penilaian berarti yang dimaksudkan terampil disini ialah terampil menguasai semua konsep, teori serta dapat mengaplikasikannya di dalam proses penilaian yang sesuai dengan standar yang ditetapkan pemerintah (Supriyono, 2006).

Dengan demikian, perbedaan pemahaman pendidik terhadap standar penilaian bisa dipengaruhi oleh berbagai faktor, salah satu solusi yang dihadirkan untuk mengatasi perbedaan tersebut ialah dengan melakukan pertukaran pengetahuan melalui dengan sharing pengetahuan, atau dengan melakukan sosialisasi.

\section{SIMPULAN}

Berdasarkan analisis data dan pembahasan, maka diperoleh adanya variasi pemahaman tentang standar penilaian di madrasah pada berbagai komponen pendidik dan tenaga kependidikan. Selain itu, ada pula variasi pemahaman kepala madrasah dan guru terhadap komponen-komponen dari standar penilaian yang dilaksanakan di MTs AsSa'adah. Sebagai salah satu upaya dalam meningkatan pemahaman pendidik bisa dilakukan dengan mengadakan diklat, sosialisasi, serta pelatihan-pelatihan mengenai standar penilaian.sehingga tidak terjadi ketimpangan pemahaman antara kepala sekolah dengan pendidik. 


\section{REFERENSI}

Amaroh, S. (n.d.). Urgensi Pelatihan bagi Peningkatan Profesionalitas Guru. Retrieved from https://storage.googleapis.com/google-code-archivedownloads/v2/code.google.com/imadiklus/3 Siti Amaroh. URGENSI PELATIHAN BAGI PENINGKATAN PROFESIONALITAS GURU.pdf

Amrullah, M. A. (2017). Sistem Penilaian dalam Pembelajaran. All Professional Teachers Should Conduct a Certain Assessment in the End of Every Learning Process. Assessing Students' Learning Process Is an Integral Part of Whole Learning Process. The Kinds of Test May Take in Various Forms: Oral Test, Written Test, P, 7(2). Retrieved from http:// ejournal.radenintan.ac.id/ index.php/albayan

Anjelica, Sharon, dkk. (2017). Manfaat Sosialisasi Program Badan Penyelenggara Jaminan Sosial Kesehatan Bagi Masyarakat di Kecamatan Sario. Sosial, VI(1).

Baharun, H. (2016). Penilaian Berbasis Kelas pada Pembelajaran Pendidikan Agama Islam di Madrasah. MODELING: Jurnal Program Studi PGMI, 3(2), 204-216.

Departemen Pendidikan Nasional. (2003). Undang-Undang Nomor 20 Tahun 2003 tentang Sistem Pendidikan Nasional. Jakart: Departemen Pendidikan Nasional.

Excerpt, A., \& Entry, O. (2006). Socialization, (1994).

Hamsinah. (2016). Pengembangan Sumber Daya Manusia Bagi Tenaga Guru. Soaial Pendidikan, 3(1). Retrieved from http://journal.uinjkt.ac.id/index.php/SOSIOFITK/article/view/3799

Kamil, M. (2010). Model penelitian dan pelatihan. Bandung: Alfabeta.

Mei Chuo, C. (2011). Student Teachers Socialization Development By Teaching Blog: Reflections and Socialization Strategies. Journal of Educational Technology, 10(2). Retrieved from https://files.eric.ed.gov/fulltext/EJ932238.pdf

Mustikawan, A. (2013). Evaluasi Sistem Penilaian di PTAI. Tarbiyah, IX(1). Retrieved from http:/ / ejournal.uin-malang.ac.id/index.php/elhikmah

Rahman, T. (2016). Menggagas Pengelolaan Penilaian Untuk Peningkatan Pembelajaran. Pendidikan Islam, 1(1). Retrieved from http://ojs.ppsibrahimy.ac.id/index.php/jpii

Rusdin. (2017). Pendidikan dan Pelatihan sebagai Sarana Peningkatan Kompetensi Guru di SMP Negeri 2 Linggang Bigung. Ilmu Komunikasi, 5(4). Retrieved from http:/ /ejournals.unmul.ac.id/index.php/JAR/article/view/885

Raharjo. (2014). Kontribusi Delapan Standar Nasional Pendidikan Terhadap Pencapaian Prestasi Belajar. Standar Pendidikan. Retrieved from http://jurnaldikbud. kemdikbud.go.id/index.php/jpnk/article/download/160/146

Raharjo, S. B. (2014). Kontribusi Delapan Standar Nasional Pendidikan terhadap Pencapaian Prestasi Belajar. Jurnal Pendidikan dan Kebudayaan, 20(4), 470-482. 
Rembang, P., Hatidja, D., \& Komalig, H. (2017). Deskripsi SMA/SMK Di Kabupaten Minahasa Tenggara Berdasarkan Indikator Standar Nasional Pendidikan Berbasis Evaluasi Diri Sekolah (Standar Sarana Dan Prasarana, Standar Pengelolaan, Standar Pembiayaan Pendidikan Dan Standar Penilaian Pendidikan). Jurnal Ilmiah Sains, 17(2), 117-125.

Soerjono, S. (2009). Sosiologi Suatu Pengantar. Jakarta: Rajawali Press.

Sudjana, N. (n.d.). Penilaian Hasil Proses Belajar Mengajar. Bandung: PT. Remaja Rosdakarya.

Supriyono. (2006). Desain Diklat Pendidk dan tenaga Kependidikan. Jurnal Ilmiah, 1(2). Retrieved from http://journal.unj.ac.id/unj/index.php/jiv/article/download/2761/2068

Susila, I. K. (2012). Pengembangan Instrumen Penilaian Unjuk Kerja (Performance Assesment) Laboratorium Pada Mata Pelajaran Fisika Sesuai Kurikulum Tingkat Satuan Pendidikan SMA Kelas X di Kabupaten Gianyar. Evaluasi Pendidikan. Retrieved from https://anzdoc.com/artikel-oleh-i-ketut-susila-nim.html

Syah, M. (2011). Psikologi Pendidikan dengan Pendekatan Baru. Bandung: Remaja Rosdakarya.

Wursanto. (2003). Etika Komunikasi. Yogyakarta: Kansius.

Miarso, Y. (2008). Peningkatan kualifikasi guru dalam perspektif teknologi pendidikan. Jurnal Pendidikan Penabur, 7(10), 66-76.

Baharun, H. (2016). Penilaian Berbasis Kelas pada Pembelajaran Pendidikan Agama Islam di Madrasah. MODELING: Jurnal Program Studi PGMI, 3(2), 204-216. 